\title{
Critical threat associated with carbapenem- resistant gram-negative bacteria: prioritizing water matrices in addressing total antibiotic resistance
}

\author{
Anthony A. Adegoke ${ }^{1 *}$, Opeyemi K. Fatunla ${ }^{1}$ and Anthony I. Okoh ${ }^{2,3}$
}

\begin{abstract}
Purpose: The World Health Organization (WHO) in 2017 classified some carbapenem-resistant Gram-negative bacteria into a critical criterial group for research and development. This study reviews the need to prioritize the water matrices as hotspot in the development and transfer of antibiotic resistance determinants, where future total resistant superbug may emerge.

Methods: Published articles on Google Scholars, PubMed/Medline Search and other search tools were selected, with special interest in articles published in indexed journals. Search criteria were based on antibiotic resistance, antibiotic resistance determinants and emerging trend in the reported trend of antibiotic resistance among bacteria from water matrices.

Results: Research reports around the globe have identified carbapenem-resistant Gram-negative bacteria (CRGNB) in water matrices. These CRGNB have also been found to be resistant to other antibiotics in the last line of defence. Molecular typing of some carbapenem-resistant Enterobacteriaceae (CRE) in the environment through pulsed-field electrophoresis showed them to be the same as those in the hospital settings. CRGNB from various water matrices have been reported to harbour carbapenem resistance genes with phenotypic expression of carbapenemases' production. Water habitat provides a conducive environment for the development and spread of carbapenem resistance. Factors like residual antibiotics (RAbs), metals, biocide and water-borne mutagens aid the emergence of the resistance in water matrices. Irrespective of where it was contacted, carbapenem-resistant bacteria have poor prognosis. This is exemplified by resistance to 26 different antibiotics recently in the USA. The human health risk associated with the use of water harbouring these pathogens for irrigating fruits and vegetables may be alarming.

Conclusion: The reports of the rising trend of antibiotic resistance also necessitate prioritizing water matrices when addressing the problems from the reservoir. Surveillance and strict isolation, education and enlightenment, strict compliance with multiple barrier approach of the WHO and more search for more potent antibiotics remain some of the antidotes against the development and spread of resistance through the water matrices as discussed in this article.
\end{abstract}

Keywords: Water matrices, Carbapenem, Carbapenemases, Metals, Total resistance

\footnotetext{
*Correspondence: aadegoke@ufh.ac.za; aayodegoke@gmail.com

'Department of Microbiology, University of Uyo, PMB 1017, Akwa-lbom State,

Uyo, Nigeria

Full list of author information is available at the end of the article
}

(C) The Author(s). 2020 Open Access This article is licensed under a Creative Commons Attribution 4.0 International License, which permits use, sharing, adaptation, distribution and reproduction in any medium or format, as long as you give appropriate credit to the original author(s) and the source, provide a link to the Creative Commons licence, and indicate if changes were made. The images or other third party material in this article are included in the article's Creative Commons licence, unless indicated otherwise in a credit line to the material. If material is not included in the article's Creative Commons licence and your intended use is not permitted by statutory regulation or exceeds the permitted use, you will need to obtain permission directly from the copyright holder. To view a copy of this licence, visit http://creativecommons.org/licenses/by/4.0/ 


\section{Introduction}

The dangerous trend in the evolution of difficult-tocontrol bacteria, which sometimes originate from the hospitals and are released to the water matrices through the wastewater, is alarming. Health-related news around the globe are agoggled with the worsened prognosis of bacterial infection, which has been leading to the death of the patients. This is because the bacteria are becoming resistant to the existing antibiotics in the last line of defence. Statnews.com reported in January 2017 about the death of a Nevada woman who died of a superbug resistant to every available antibiotic in the USA. Worthy of note in this report was that the woman was infected with potential water contaminant bacteria, Enterobacteriaceae, which in this case was carbapenem-resistant Enterobacteriaceae, CRE. The death of the woman due to failure of 26 different antibiotics made the doctor in charge termed CRE a "nightmare bacteria" (Branswell, 2017). Earlier, another report from the "Science for the Curious Discover, 2015" elaborated on the discovery of a strain of Escherichia coli, which has shown resistance to all existing antibiotics. The said $E$. coli was resistant to all the antibiotics in the last line of defence, including colistin, known earlier for consistent effectiveness against the bacterium and other Gram-negative bacteria (GNB) (Zavascki et al. 2007). There is a high level of concern among the health care practitioners and global regulatory bodies due to the rising antibiotic resistance rates. The World Health Organization (WHO) (2017) published the list of bacteria requiring more input in research and development. They include major Gramnegative bacteria, which are known as nosocomial pathogens as well as water-related pathogens (Ramirez-Castillo et al. 2015; Stenström et al. 2016). These pathogens, which include carbapenem-resistant Acinetobacter baumannii, carbapenem-resistant Pseudomonas aeruginosa, and carbapenem-resistant, ESBL-producing Enterobacteriaceae with critical priority (Ramirez-Castillo et al. 2015), are known water-borne pathogens (Ramirez-Castillo et al. 2015; Stenström et al. 2016). Water-borne $P$. aeruginosa's relatives, Stenotrophomonas maltophilia and Burkholderia cepacia, have been classified for posing a great threat as having intrinsic extreme drug-resistant statuses (McGowan, 2006; Adegoke and Okoh, 2015). Water matrices therefore remain the phases for consideration in the emergence and spread of antibiotic resistance among Gram-negative pathogens (Adegoke et al. 2017). These groups of Gram-negative bacteria are of threat in water-borne infection as well as serious nosocomial infections due to their production of extendedspectrum $\beta$-lactamases (ESBLs). The enzyme (ESBLs) makes the bacteria resistant to the third-generation cephalosporins and results in prolonged hospital stays, higher health care costs and increased mortality.
Resistance to antibiotics in the last line of defence by either the environmental strains or the clinical strains of bacterial pathogens leads to total drug resistance. Based on the clinical outcomes in the reports above, carbapenem-resistant Gram-negative bacteria are of greater threat in the emergence of total antibiotic resistance.

Water matrices are major breeding ground in the emergence of this magnitude of resistance, and they are continually impacted with multidrug-resistant (MDR) bacterial isolates from the hospital through poorly treated hospital sewage (Picão et al. 2013; Blaak et al. 2015). When these MDR bacteria include species in the genera Acinetobacter, Pseudomonas, Aeromonas, Stenotrophomonas among others, their chances of survival in these matrices are high. They get exposed to the residual antibiotics in this environment and may develop a high level of resistance (Adegoke et al. 2017). Carbapenemresistant bacteria are, in principle, heading towards total antibiotic resistance, especially when they show resistance to colistin and fluoroquinolone (Endimiani et al. 2009; Kontopoulou et al. 2010; Zarkotou et al. 2010). This is usually peculiar for carbapenem and fluoroquinolone resistance with their determinants residing in the plasmid (Endimiani et al. 2009). Exposure to antibiotic residues in the environment (especially in the water matrices) or by self-medication where further development of resistance can be developed makes these bacteria be of greater threat with potentials to resist more antibiotics (Adegoke et al. 2017). This article examines the carbapenem-resistant Gram-negative bacteria as reported in water matrices, their reported carbapenemase production and the presence of other resistance determinants, the fate of these resistant bugs in the water environment, their critical impending threat and ways to mitigate the risks.

\section{Methods}

\section{Search criteria}

Published articles on Google Scholars, PubMed/Medline Search and other search tools were selected, with special interest in articles published in indexed journals. Search criteria were based on "antibiotic resistance", "antibiotic resistance determinants" and "emerging trend in the reported trend of antibiotic resistance among bacteria from water matrices". The keywords and search terms employed include, but not limited to, "carbapenem resistance AND water matrices, public health threat" AND "carbapenem resistance AND water matrices", "carbapenem; carbapenemases AND water matrices"; "metals; carbapenem resistance AND total resistance AND threat". "antibiotic resistant genes OR antibiotic resistant bacteria". For each case, the search outcomes were reviewed by the authors. 


\section{Inclusion and exclusion criteria}

Articles published in the English language were selected for this study with less emphasis on the study location or year of publication. Articles which reported antibiotic resistance in surface water, tap water, wastewater, recreation water, etc. with emphasis on carbapenem antibiotics were considered. Other studies in clinical settings that also reported the threats associated with the resistance or mechanisms of resistance reported already in water matrices were sometimes used for comparative illustrations. Articles written in other languages were excluded.

\section{Extraction of data}

Information on the reported carbapenem resistance factors favouring the emergence of antibiotic resistance in water environment was extracted, and the distribution of associated threat of carbapenemases and reported mortality to carbapenem resistance towards total antibiotic resistance pattern etc. were extracted. Relevant tables and illustrative figures containing important summaries of resistance threat, associated factor and interpretive standards were developed.

\section{Results}

Out of about 536 articles searched, only 127 publications matched the described inclusion criteria and were eventually used for this study.

\section{$\beta$-Lactamases produced by gram-negative bacteria}

Gram-negative bacteria produce various $\beta$-lactam antibiotic degrading enzymes which destroy the penicillins, some inhibitor-based $\beta$-lactam antibiotics, cephalosporins, carbapenem etc. depending on the spectrum of the enzymes' activity. So, the beta-lactamases are categorized as depicted in Fig. 1.

The beta-lactamases contributing to the threat of antibiotic resistance include the following: a. Penicillases which are those that are effective against the $\beta$-lactam ring of the penicillin antibiotics, but not effective against extended-spectrum antibiotics like cephalosporins

b. Extended-spectrum beta-lactamases (ESBLs): ESBLs hydrolyze extended-spectrum cephalosporins with an oxyimino side chain including cefotaxime, ceftriaxone and ceftazidime, as well as the oxyiminomonobactam aztreonam. They sometimes originate from genes coding for phenotypic production of beta-lactamases like TEM-1, TEM-2 or SHV-1 by mutations in which the amino acid configuration in the active site of these $\beta$-lactamases has been changed. There are reports on the rising detection of some specific ESBLs (Rodríguez-Baño and Pascual 2008) which are coded for by the plasmid and make the Cephem drugs ineffective. The ESBLs limit the treatment option for a broad range of infection from Gram-negative bacteria. A case of water-borne infection caused by ESBL producers in children or neonates would be difficult to treat, especially if the aetiology is carbapenem resistant, since fluoroquinolones are least indicated (unsafe) for these categories of patients (Goldman and Kearns 2010; Adefurin et al. 2011; Choi et al. 2013). ESBLs on its own do not inactivate carbapenems, but can confer resistance to carbapenem due to subsequent chromosomal porin mutations limiting the penetration of $\beta$-lactam agents in the bacteria (Lutgring and Limbago 2016).

\section{Types of ESBLs}

\section{TEM (Temoneira) beta-lactamases (class a)}

TEM-1 is the most prevalent beta-lactamase in Gramnegative bacteria. It is produced by majority of ampicillin resistance in E. coli (Ghafourian et al. 2015) "ampicillin and penicillin-resistance in" Haemophilus influenzae and Neisseria gonorrhoeae. The shield provided around the amino acid substitutions necessitated clustering around by ESBLs before access to the oxyimino-beta-lactam

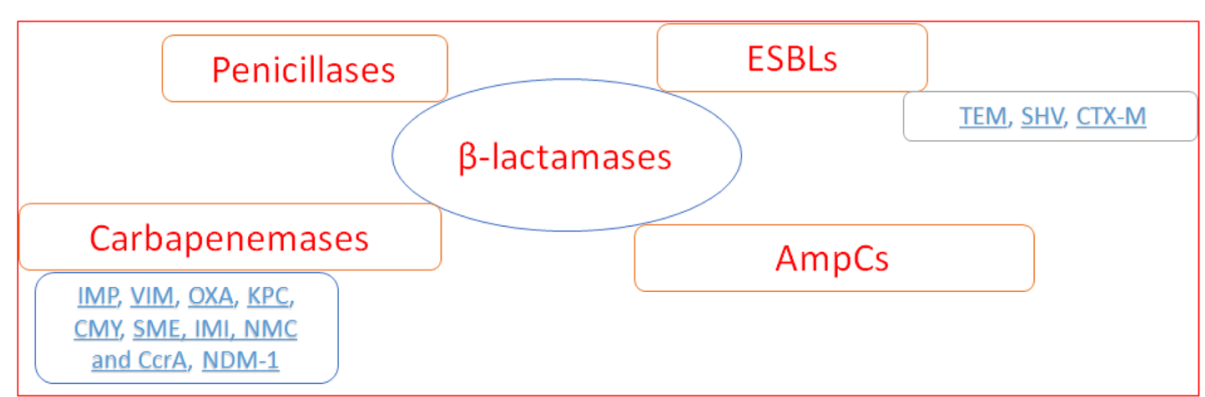

Fig. $1 \beta$-Lactamases produced by Gram-negative bacteria. Key: IMP-type carbapenemases (metallo- $\beta$-lactamases) (class B), VIM (verona integronencoded metallo- $\beta$-lactamase) (class B), OXA (oxacillinase) group of $\beta$-lactamases (class D), KPC (K. pneumoniae carbapenemase) (class A), CMY (class C), SME, IMI, NMC (metallo- $\beta$-lactamases) and CcrA, and NDM-1 (New Delhi metallo- $\beta$-lactamase) (class B) 
substrates. Protease inhibitor, e.g. clavulanic acid, possesses activity against the ESBLs because of prior exposure of active site as induced by the presence of beta-lactam substrates. Out of about 140 different TEM betalactamase possible owing to changes via combinations, only TEM-10, TEM-12 and TEM-26 are prevalent in the USA (Bradford 2001; Paterson et al. 2003; Bush 2008). In surface water, Guyomard-Rabenirina et al. (2017) reported the detection of multidrug-resistant $E$. coli strain with TEM-1 beta-lactamase genes, showing the importance of water matrices in cycling of resistance genes in nature.

\section{SHV beta-lactamases (class a)}

Both TEM-1 and SHV-1 possess structural similarities with $68 \%$ similar amino acids.

The SHV-1 beta-lactamase stands as the most prevalent in $K$. pneumoniae. It undergoes conformational amino acid changes around the active sites to bring about 60 varieties of its enzyme, out of which SHV-5 and SHV-12 are the most prevalent (Paterson et al. 2003). The genes for the SHV-ESBLs reside on selftransmissible plasmids. The plasmids usually bear resistance genes to other antibiotics. The ESBL which is ubiquitous and rampant among Enterobacteriaceae globally has been described by Liakopoulos et al. (2016) as neglected yet ubiquitous. It is vital for resistance (Liu et al. 2016). Liu et al. (2016) showed that the location and transmission efficiency of SHV-12 ESBL are directly linked with the antibiotic resistance of Enterobacter cloacae. Conjugation assays conducted by Liu et al. (2016) which were transconjugated into E. coli $\mathrm{C} 600$ showed 84\% partial expression and $10 \%$ complete expression of resistance from E. cloacae by plasmid-borne SHV-12 ESBL genes.

In South Western Nigeria, Adesoji and Ogunjobi (2016) observed the combinations of bla $\mathrm{SHV}_{\mathrm{SHV}}+\mathrm{bla}_{\mathrm{TEM}}$ in 11 Klebsiella species in water distribution channels buttressing the importance of water matrices in the distribution of the resistance determinants.

\section{CTX-M beta-lactamases (class a)}

These were name in more relativity to cefotaxime than other oxyimino-beta-lactam substrates like ceftazidime, ceftriaxone or cefepime. They have been widely reported in water-borne Gram-negative isolates around the globe (Adegoke and Okoh 2011; Stenström et al. 2016; Adegoke et al. 2017). Plasmids carrying $\mathrm{bla}_{C T X-M}$ genes usually carry other antibiotic resistance determinants such as plasmid-mediated quinolone resistance (Canton et al. 2002). CTX-M enzymes, which contain over 80 CTX-M enzymes, have just about $40 \%$ identity with SHV and TEM. In South America, these enzymes are prevalently detected in E. coli and other species of Enterobacteriaceae (Delgado et al. 2016). Delgado et al. (2016) detected variants of CTX-M, with CTX-M-15 being the highest as well as 2 rare variants of CTX-M (CTX-M-15) which has also been reported in K. pneumoniae ATCC BAA-2146 in Asia (South Korea) (Cho et al. 2015). Environmental detection of these enzymes and its determinants, as well as other antibiotic resistance determinants previously believed to be in the exclusive preserve of the clinical isolates, calls for caution in handling environmental samples like the clinical samples (Adegoke and Okoh 2015). It also points to the importance of the environment, especially the water matrices, in the emergence and/or distribution of resistance. Isolates with these determinants in the environment have greater tendencies for further exposures to several mutagens in the environment (e.g. wastewater) than in hospital, increasing their resistant threat (Lutgring and Limbago 2016). This might also increase.

\section{Other plasmid-mediated ESBLS}

Rarely detected plasmid-mediated ESBLs which include "PER, VEB, GES and IBC" beta-lactamases are predominant among $P$. aeruginosa. Though rare as earlier noted, they have been isolated in various countries at different times. In South Africa, Adegoke and Okoh (2014) reported the maiden detection of GES-5 in South Africa which was the second in clinically isolated $P$. aeruginosa. On the environment, Al Yousef et al. (2016) discovered 83.3\% VEB in E. coli from some Saudi Arabian household water samples in which the isolates showed $100 \%$ resistance to ampicillin, cefazolin and piperacillin. Korea, Belgium, Romania, France, the USA and Turkey have also prevalently reported PER-1 in Acinetobacter species (Peleg et al. 2008). Some of these rare enzymes (e.g. IBC-1, BES-1, IBC-1 etc.) contribute substantially to the emergence of resistance to antibiotics in the last line of defence among Enterobacteriaceae through mutation. This has been reported to be of concern in the usually prioritized hospital settings and mostly overlooked environment (D'Costa et al. 2006).

\section{Factors for the emergence of antibiotic resistance in water environment}

The emergence as well as progression to higher trend of antibiotic resistance in the water matrices is possible due to a number of factors or water components, which include residual antibiotics (RAbs) in water, metals, biocides and mutagenic contaminants (Zuccato et al. 2005). Table 1 shows the mechanisms by which the components may induce resistance or its progression as well as specific examples of reported or relevant cases. Exposure to the listed components (Table 1) may lead to progression of resistance in the following order: single antibiotic resistance (AR), multidrug resistance (MDR), extensive drug resistance (EDR), pandrug resistance (PDR), extreme 
Table 1 Factors favouring the emergence of antibiotic resistance in the water environment

\begin{tabular}{|c|c|c|c|}
\hline Water components/contaminants & Mechanism of resistance & Specific applicable example & References \\
\hline Residual antibiotics (RAbs) & $\begin{array}{l}\text { Bacterial exposure to } \\
\text { sublethal concentration } \\
\text { of RAbs leads to the } \\
\text { emergence of resistance, } \\
\text { post exposure resistance } \\
\text { via selection for specific } \\
\text { antibiotic-resistant genes } \\
\text { (ARGs) or resistance } \\
\text { determinants, bacterial } \\
\text { mutation as a form of } \\
\text { adaptation to the } \\
\text { antibiotics in water } \\
\text { habitat }\end{array}$ & $\begin{array}{l}\beta \text {-Lactams by mutations in PBP5 } \\
\text { and PBP2 among aquatic } \\
\text { Enterococcus faecium and } \\
\text { Proteus mirabilis }\end{array}$ & $\begin{array}{l}\text { Adegoke et al. (2017); Li et al. } \\
\text { (2009); Sosa et al. (2006) }\end{array}$ \\
\hline \multirow[t]{3}{*}{ Metals } & \multirow[t]{3}{*}{$\begin{array}{l}\text { Co-selection of resistance } \\
\text { genes against antibiotics } \\
\text { in which exposure/selection } \\
\text { for metal resistance leads } \\
\text { to antibiotic resistance }\end{array}$} & $\begin{array}{l}\text { merA and KPC beta-lactamase. } \\
\text { This may affect a wide range } \\
\text { of } \beta \text {-lactam antibiotics including } \\
\text { the carbapenems }\end{array}$ & $\begin{array}{l}\text { Romero et al. (2017); Pal et al. } \\
\text { (2015); Baker-Austin et al. (2006); } \\
\text { Fang et al. (2016) }\end{array}$ \\
\hline & & $\begin{array}{l}\text { Copper and silver may develop } \\
\text { co-occurrence of resistance to } \\
\text { beta-lactam and fluoroquinolone }\end{array}$ & Fang et al. (2016) \\
\hline & & $\begin{array}{l}\text { Copper, mercury and silver } \\
\text { Colistin may develop co- } \\
\text { occurrence of resistance to } \\
\text { ampicillin, sulfonamide, } \\
\text { tetracycline, streptomycin } \\
\text { and chloramphenicol }\end{array}$ & Li et al. (2016); Campos et al. (2016) \\
\hline Biocide & $\begin{array}{l}\text { Co-selection of resistance } \\
\text { genes against antibiotics } \\
\text { in which exposure/selection } \\
\text { for biocide resistance leads } \\
\text { to antibiotic resistance }\end{array}$ & $\begin{array}{l}\text { Acriflavine, chlorhexidine } \\
\text { and ethidium bromide may } \\
\text { develop co-occurrence of } \\
\text { resistance to gentamicin } \\
\text { and amikacin }\end{array}$ & Wales and Davies (2015) \\
\hline Water-borne mutagens & $\begin{array}{l}\text { Alteration of drug target } \\
\text { by mutagenesis }\end{array}$ & $\begin{array}{l}\text { Bromoacetamide (BACAm), } \\
\text { trichloroacetonitrile (TCAN) } \\
\text { or tribromonitromethane } \\
\text { (TBNM) increased the } \\
\text { resistance of Pseudomonas } \\
\text { aeruginosa PAO1 to both } \\
\text { individual and multiple } \\
\text { antibiotics (ciprofloxacin, } \\
\text { gentamicin, polymyxin } \\
\text { B, rifampin, tetracycline, } \\
\text { ciprofloxacin + gentamicin } \\
\text { and ciprofloxacin + tetracycline) }\end{array}$ & $\begin{array}{l}\text { Lv et al. (2014); Lv et al. (2015); } \\
\text { Watanabe et al. (2006) }\end{array}$ \\
\hline
\end{tabular}

drug resistance (XDR) and total drug resistance (TDR) as elaborated by Adegoke et al. (2017).

Carbapenem resistance is an obvious XDR. A progression via exposure to mutagens (mutation), RAbs, metals, biocides etc. in water environment can easily lead to their progression to TDR. Water matrices therefore remain an aspect of the environment that requires important action in tracking and mitigating the risk associated with antibiotic resistance.

\section{Distribution and associated threat of carbapenemases}

As earlier noted in the various clinical reports of the gradual emergence of total drug resistance, carbapenemresistant bacteria, also known to be carbapenemases' producers, resist all existing antibiotics. This has made carbapenemases to be recognized for posing a new threat, inactivating the last lines in antibiotic defence. Following the detection of the classic carbapenemases (metallo- $\beta$-lactamases, Ambler class B) in the 1990s, the distribution of different metallo- $\beta$-lactamase genes globally has been reported (Picao et al. 2013; Berrazeg et al. 2014; 59. Adam and Elhag 2018). In 2003, Klebsiella pneumonieae carbapenemases (KPC, Ambler class A serin $\beta$-lactamase) which are predominantly found in Klebsiella species (also in Enterobacteriaceae as well as other Gram-negative bacteria) were reported in North Carolina and it has spread across the globe (Yigit et al. 2001; Arnold et al. 2011). For Enterobacteriaceae, they singlehandedly house OXA-48 and its derivatives (Canton 2002; Nordmann and Poirel 2002; Nordmann et al. 2012). Meanwhile, metallo-beta-lactamases that used to be less rampant in the USA are now 
becoming the most prevalent for carbapenem resistance (Canton et al. 2012), leading way to the "emergence of total drug resistance (TDR)". The gene $b l a_{K P C}$, which codes for the KPC, is widely disseminated among species and geographical location. It is located within a Tn3-type transposon, Tn4401, with potential for insertion into various plasmids of GNB. Plasmids carrying blaKPC are usually linked with resistance determinants for antibiotics (Asit et al. 2016). Carbapenemase production is highly significant in the emergence of resistance, especially among carbapenemresistant Enterobacteriaceae (CRE).

The presence of carbapenemase-producing Enterobacteriaceae (CPE) in a sample may connote the expression serin $\beta$-lactamases. Carbapenemase production is commonly detected among Escherichia coli, Klebsiella pneumoniae, Pseudomonas aeruginosa and Acinetobacter baumannii (Bialvaei et al. 2015). There is also an increase in the likelihood of detecting carbapenemases in Central Europe. KPC is endemic in some countries like Italy or Greece (Nordmann et al. 2011; Hoenigl et al. 2012). Poirel et al. (2012) also reported the detection of KPC-producing Enterobacteriaceae from wastewater and river-water samples in Portugal, just as bacterial isolates from human in Austria were reported to harbour NDM1, KPC, VIM, IMP and OXA-48. There is therefore an upward surge in the detection of KPC-producing Enterobacteriaceae (Nordmann et al. 2011; Zarfel et al. 2011; Heller et al. 2012).

Studies have shown that OXA-48 is rampant in Austria (Nordmann et al. 2011; Zarfel et al. 2011; Heller et al. 2012). However, the detection of "metallo- $\beta$-lactamase" has not been frequently reported. That was the first report of "OXA-48-producing Enterobacteriaceae in Taiwan and the second report to identify blaOXA-48 on an IncA/C plasmid in $K$. pneumoniae". Potron et al. (2011) gave a report on the intercontinental spread of OXA-48 beta-lactamase producing Enterobacteriaceae over 11 years. The report showed the emergence of an endemic situation occasioned by repeated importation of OXA-48 beta-lactamase producers in Europe and particularly in France. As far back as 2005, Austria had records of metallo- $\beta$-lactamase carbapenemase (Zarfel et al. 2011). Metallo- $\beta$-lactamases are recognized for environmental spread (Isozumi et al. 2012) but may obviously be following KPC and OXA-48 in the human and clinical settings. Both KPC-2 and OXA-48 carbapenemase-harbouring Enterobacteriaceae have been reported in an Austrian wastewater (Galler et al. 2014). This might be a true reflection of the statuses of the Enterobacteriaceae in the Austrian human environment as wastewater is an early warning system of the situation in the human population before outbreaks (Hellmér et al. 2014). This also brings to bare the need for the wastewater treatment plant to scale up the process to raise treatment efficiency. Hrenovic et al. (2017) reported the 54\% reduction of the carbapenemresistant bacterial population in the secondary wastewater treatment plants (WWTPs). The report shows that it is possible to stop the spread of carbapenem-resistant bacteria and its associated risk in the wastewater reuse by upscaling the WWTPs.

The spread to the environment through the wastewater is very frequent which in turn impacts the food cycles, human and animal health as well as contaminated inanimate objects. Environmental disseminations of KPC- and OXA-48-producing Enterobacteriaceae in Austria have been reported (Kittinger et al. 2016). It was found to be more prominent in the rivers and animals (Galler et al. 2014; Kittinger et al. 2016), which may mean that more animals are exposed and shed the organisms to the environment. These deposits in the environment are washed by runoffs into the rivers where they are recirculated to more animals by exposure. Meanwhile, attentions that are more specific have been drawn to the presence of NDM-1 in E. coli ST-type 131 in community-based infection as the bacteria are known for CTX-M ESBL production (Adegoke et al. 2017; Potron et al. 2011; Diancourt et al. 2005).

It is important to note that one CRE and CPE are released to the environment as well as to the food chain through wastewater from the infected residence or hospital. Several studies (Stenström et al. 2016; Xu et al. (2011), Liu et al. (2010) and Reinthaler et al. (2013) reported the presence of multidrug-resistant bacteria in the aquatic environment imparted by wastewater. Some of these studies implied that the production of carbapenemases produced by aquatic bacteria follows the same pattern as those by clinical strains. This is exemplified by the reports of water-borne carbapenemase-producing Enterobacteriaceae (Zurfluh et al. 2013).

\section{Mortality related to $C R B$}

Carbapenem-resistant bacteria (CRB) have been reported with poor prognosis, irrespective of the source of infection: either community-acquired or nosocomial (Bennett et al. 2009; Zhang et al. 2016). There have been controversies around recovery from the carbapenem resistance as cases of co-resistance to other drugs leading to death have been reported (Branswell 2017; Bennett et al. 2009; Zhang et al. 2016). Zhang et al. (2016) observed that though carbapenem resistance had a damaging impact on the mortality of $P$. aeruginosa bacteremia, its association with mortality is still controversial. Bennett et al. (2009) deduced that $26-44 \%$ of deaths were observed in 7 studies due to carbapenem resistance and the course may be a bit different when bacteraemia is involved. Zhang et al. (2016) reported that four studies reported 
8-18.4\% mortality due to carbapenem resistance within 30-day mortality. Buehrle et al. (2017) predicted certain factors that aid the course of carbapenem-resistant Pseudomonas aeruginosa (CRPA) bacteraemia towards mortality, in which early active therapy would have been redemptive. This shows that various factors facilitate the course of recovery or death in carbapenem-resistant bacterial infection, making it difficult to treat. The death of the US woman, earlier mentioned in this article due to carbapenem-resistant Enterobacteriaceae and subsequent failure of 26 different antibiotics (Branswell 2017), continues to position the carbapenem-resistant Gramnegative bacteria as a threat in both clinical settings and the environment. Liu et al. (2016) drew a conclusion that "CRPA had significantly higher mortality than those infected with carbapenem-susceptible Pseudomonas aeruginosa (CSPA)". These reports informed the classification of these CRB in the critical priority list, for which new $\mathrm{R}$ and D antibiotics are required (WHO 2017).

\section{Mitigating the public health risks associated with CRB}

Some schools of thought believe that the CRB from the hospital settings are responsible for the contamination of the environments (Liu et al. 2015). Others believe that the emergence of antibiotic resistance including CRB occurs in the environment due to exposure to antibiotic residues (Khan et al. 2013). The latter believe that water matrices create a very conducive environment for the development of antibiotic resistance ( $\mathrm{Li}$ et al. 2009; Khan et al. 2013) even when there is no hospital in the vicinity. These researchers submitted that antibiotic resistance genes ( $\mathrm{Li}$ et al. 2009; Davies and Davies 2010; Zhang et al. 2011) and other resistance determinants (Li et al. 2009; Manhal and Hashim 2016) in environments are exchanged in the environment. Adegoke et al. (2017) elaborated on the role of biofilms formed in wastewater and the surface water environments in providing a conducive avenue for the water-borne bacteria to exchange resistance determinants. Reports acknowledge that both the hospital settings and the community are important in the emergence and dissemination of antibiotic resistance (Zhang et al. 2011; Adegoke et al. 2010). Water matrices become very important because there have been reports of antibiotic resistance, including carbapenem resistance in various types of water, including drinking water (Table 2).

Environment, especially the water matrices, is important to prioritize in finding solutions to the threat associated with CRE, CRB and resistance to other antibiotics in the future. Certain steps to take are itemized as follows.

\section{Surveillance and strict isolation}

Following typing by pulsed-field gel electrophoresis, it has been reported that both clinical and environmental isolates of CRB were related (Kotsana et al. 2014).
Surveillance in the environment should be intensified as much as the hospital settings to check the spread of the CRE and CRB (Calfee and Jenkins 2008; Kochar 2009; Ben-David et al. 2010; Centers for Disease Control and Prevention 2012). Patients recognized to have been colonized with CRE should be isolated to prevent being the reservoir for the spread (Munoz-Price et al. 2010a; Munoz-Price 2010b; Castilho et al. 2017). Isolation of patients with CRB is also very important. This is peculiar to those in the intensive care units (ICU). Castilho et al. (2017) reported a high incidence of carbapenem resistance (MDR) A. baumannii with the expression of OXA23 genes. Even the wastewater from the isolation ward should be specially treated onsite to prevent the accidental leakage into the surface water while being transported through the municipal wastewater treatment plants. There have been reports showing that the drains, sinks, and faucets in hospitals are usually colonized by carbapenemase-producing Klebsiella pneumoniae and Pseudomonas aeruginosa (Gordon et al. 2017). These Gram-negative bacteria, known for potentials to survive in the environment and water matrices, may pose a threat if released with wastewater, especially when there are accidental leakages. This shows the need to ensure the treatment of wastewater from hospital settings onsite and to put in place an automated recall system that returns the undone wastewater effluent for retreatment chambers. The existing WWTPs receiving wastewater from hospitals should be upgraded with modern facilities to ensure the eradication of CRB. It is worthwhile to ensure that hospital wastewater for reuse must be free of CRB to avoid the threat associated with such reuse. Due to the fund required, this preventive measure would need support in every country adopting locally, regionally and nationally.

While suggesting the way to alleviate the spread of carbapenem resistance, Palmore and Henderson (2013) recommended detailed environmental decontamination after aggressive microbial surveillance. Kochar et al. (2009) had reported that improved decontamination of hands and environmental surfaces as well as rectal surveillance reduced the incidence of carbapenem-resistant K. pneumoniae. Surveillance in both environment and hospital settings, especially in intensive care units, would reduce the spread as well as the need to administer colistin (An et al. 2017). Environmental cleaning and disinfection done thrice a day as well as other interventions lead to $88.3 \%$ decrease in the number of cases per thousand (odds ratio, 0.12; 95\% confidence interval, 0.03 to $0.4 ; p<0.001$ ). This also translated to a reduction in the need for the administration of carbapenems (Cheon et al. 2016) following antibiotic susceptibility testing (AST) using approved interpretive standards e.g. (Table 3). 
Table 2 Reported antibiotic profile of aquatic Gram-negative bacteria to carbapenem antibiotics in water matrices

\begin{tabular}{|c|c|c|c|c|}
\hline Carbapenem antibiotics & Sample source & Reported \% resistance & Other resistance status reported & References \\
\hline \multirow[t]{6}{*}{ Imipenem (+ cilastatin) } & Swimming pool & 26 & $\begin{array}{l}\text { 30\% Cefpodoxime-resistant } \\
\text { Pseudomonas aeruginosa }\end{array}$ & \multirow{6}{*}{$\begin{array}{l}\text { Stenström et al. (2016); } \\
\text { Picão et al. (2013); } \\
\text { Magalhães et al. (2016); } \\
\text { Freitas et al. (2019); } \\
\text { Tacao et al. (2015); } \\
\text { Akiba et al. (2016); } \\
\text { Skariyachan et al. (2015) }\end{array}$} \\
\hline & Surface freshwater & 20 & $\begin{array}{l}\text { CTX-M-ESBLs producing } \\
\text { Acinetobacter spp. }\end{array}$ & \\
\hline & Wastewater effluent & 17 & $\begin{array}{l}\text { CRE ESBLs and carbapenemase } \\
\text { producing E. coli }\end{array}$ & \\
\hline & Hospital effluent & 20.5 & $\begin{array}{l}\text { KPC-producing Aeromonas spp. } \\
\text { and Enterobacteriaceae }\end{array}$ & \\
\hline & Sewage and receiving water ${ }^{a}$ & 18 & bla $a_{N D M}$-positive plasmids & \\
\hline & River (drinking water source) & 100 & Carbapenem-resistant Citrobacter & \\
\hline \multirow[t]{5}{*}{ Ertapenem } & Wastewater influent & 61.5 & $\begin{array}{l}\text { ESBLS producing Gram- } \\
\text { negative bacteria }\end{array}$ & \multirow[t]{2}{*}{ Amine et al. (2013) } \\
\hline & Wastewater effluent & 66.6 & $\begin{array}{l}\text { ESBLS producing Gram- } \\
\text { negative bacteria }\end{array}$ & \\
\hline & \multirow[t]{3}{*}{ River (drinking water source) } & 100 & "Carbapenem-resistant" Citrobacter & \multirow[t]{3}{*}{ Skariyachan et al. (2015) } \\
\hline & & 100 & "Carbapenem-resistant" Proteus & \\
\hline & & 43 & "Carbapenem-resistant" Klebsiella & \\
\hline \multirow[t]{7}{*}{ Meropenem } & Surface freshwater & 10 & $\begin{array}{l}\text { CTX-M-ESBLs producing } \\
\text { Acinetobacter spp. }\end{array}$ & \multirow{7}{*}{$\begin{array}{l}\text { Stenström et al. (2016); } \\
\text { Akiba et al. (2016); } \\
\text { Skariyachan et al. (2015); } \\
\text { Amine et al. (2013); } \\
\text { Figueira et al. (2011) }\end{array}$} \\
\hline & Surface water & 3.9 & $\begin{array}{l}\text { Carbapenem-resistant } \\
\text { Aeromonas species }\end{array}$ & \\
\hline & Post-ozonated surface water & 3.4 & $\begin{array}{l}\text { Clonal selection occasioned } \\
\text { by ozones/mutation cum } \\
\text { fluoroquinolone resistance }\end{array}$ & \\
\hline & Hospital effluent & 16.2 & $\begin{array}{l}\text { KPC-producing Aeromonas spp. } \\
\text { and Enterobacteriaceae }\end{array}$ & \\
\hline & Wastewater influent & 10.2 & $\begin{array}{l}\text { ESBLS producing Gram- } \\
\text { negative bacteria }\end{array}$ & \\
\hline & Wastewater effluent & 8.3 & $\begin{array}{l}\text { ESBLS producing Gram- } \\
\text { negative bacteria }\end{array}$ & \\
\hline & River (drinking water source) & 42 & Carbapenem-resistant Citrobacter & \\
\hline \multirow[t]{4}{*}{ Doripenem } & River (drinking water source) & 43 & Carbapenem-resistant Salmonella & \multirow[t]{4}{*}{ Skariyachan et al. (2015) } \\
\hline & & 100 & Carbapenem-resistant Citrobacter & \\
\hline & & 0 & Carbapenem-resistant Proteus & \\
\hline & & 33 & Carbapenem-resistant Klebsiella & \\
\hline \multirow[t]{4}{*}{ Faropenem } & River (drinking water source) & 100 & Carbapenem-resistant Salmonella & \multirow[t]{4}{*}{ Skariyachan et al. (2015) } \\
\hline & & 100 & Carbapenem-resistant Citrobacter & \\
\hline & & 22 & Carbapenem-resistant Proteus & \\
\hline & & 100 & Carbapenem-resistant Klebsiella & \\
\hline
\end{tabular}

asolates were pulled together from both interlinked matrices

Table 3 CLSI interpretive standards for carbapenems (CLSI M100-2017)

\begin{tabular}{|c|c|c|c|c|c|c|c|c|}
\hline \multirow[t]{2}{*}{ Carbapenems } & \multirow[t]{2}{*}{ Disc content, $\mu \mathrm{g}$} & \multicolumn{2}{|c|}{ Resistance } & \multicolumn{2}{|c|}{ Intermediate } & \multicolumn{2}{|c|}{ Susceptible } & \multirow{2}{*}{$\begin{array}{l}\text { Remarks } \\
\mathrm{DD}=\text { disc diffusion } \\
\mathrm{MIC}=\text { minimum inhibitory } \\
\text { concentration }\end{array}$} \\
\hline & & $\mathrm{DD}$ & MIC & $\mathrm{DD}$ & $\mathrm{MIC}$ & $\mathrm{DD}$ & $\mathrm{MIC}$ & \\
\hline Imipenem & 10 & $\geq 23$ & $\leq 1$ & $20-22$ & 2 & $\leq 19$ & $\geq 4$ & Enterobacteriaceae \\
\hline Meropenem & 10 & $\geq 23$ & $\leq 1$ & $20-22$ & 2 & $\leq 19$ & $\geq 4$ & \\
\hline Ertapenem & 10 & $\geq 22$ & $\leq 0.5$ & $19-21$ & 1 & $\leq 18$ & $\geq 2$ & \\
\hline Doripenem & 10 & $\geq 23$ & $\leq 1$ & $20-22$ & 2 & $\leq 19$ & $\geq 4$ & \\
\hline
\end{tabular}




\section{Education and proper labelling of wastewater irrigated crops and vegetables}

It would be beneficial for consumers of fruits and vegetables irrigated with wastewater effluents to be educated on the associated risks (Marti et al. 2013; Thanner et al. 2016). This will be a way of guiding them on the appropriate hygienic steps to prevent being infected by the pathogens from the irrigated water (Adegoke et al. 2016). Appropriate labelling of organically grown crops should be encouraged in all countries to prepare the consumers. The action, if properly implemented, would help to achieve the focus of multifaceted, elaborate and integrated measures in line with one health approach to stop infective diseases by curbing antibiotic resistance (Founou et al. 2016). The spread of pathogens bearing resistant determinants through food chain contributes essentially to the development of antibiotic resistance (Economou and Gousia 2015) right from the first antibiotics to the latest. Figure 2 illustrates the potentials for uptake and internalization of human pathogens into crops irrigated with wastewater. These human pathogens, which might be antibiotic resistant, may persist in edible fruit which may affect immunocompromised individuals who consume them (Bouakline et al. 2000; Brenier-Pinchart et al. 2006; Golberg et al. 2011; Iwu and Okoh 2019). Some projections have shown that $85 \%$ of gastroenteritis and mortalities are from such contaminated food in which Salmonella is implicated (Deng et al. 2012; Majowicz et al. 2010).

Consumption of internalized pathogen originating from organic fertilizers or wastewater used for irrigation in uncooked food, e.g. fruits and vegetables in salad, may lead to difficult-to-treat food infection or food intoxication (Adegoke et al. 2016). This was also illustrated in Fig. 2. It is imperative to properly label crops grown using organic fertilizers appropriately for the consumers to decide based on their immune statuses.

\section{Hand hygiene and multiple barrier approach}

Hand hygiene is an all-important process to reduce the adherence of the CRE and, generally, the CRB from contacted surfaces and to avoid the spread same to other animate or inanimate surfaces (Sickbert-Bennett et al. 2004; Goroncy-Bermes et al. 2010; Macinga et al. 2011). The use of bactericidal hand gel has been advised to reduce CRE population on the hands. This is also in line

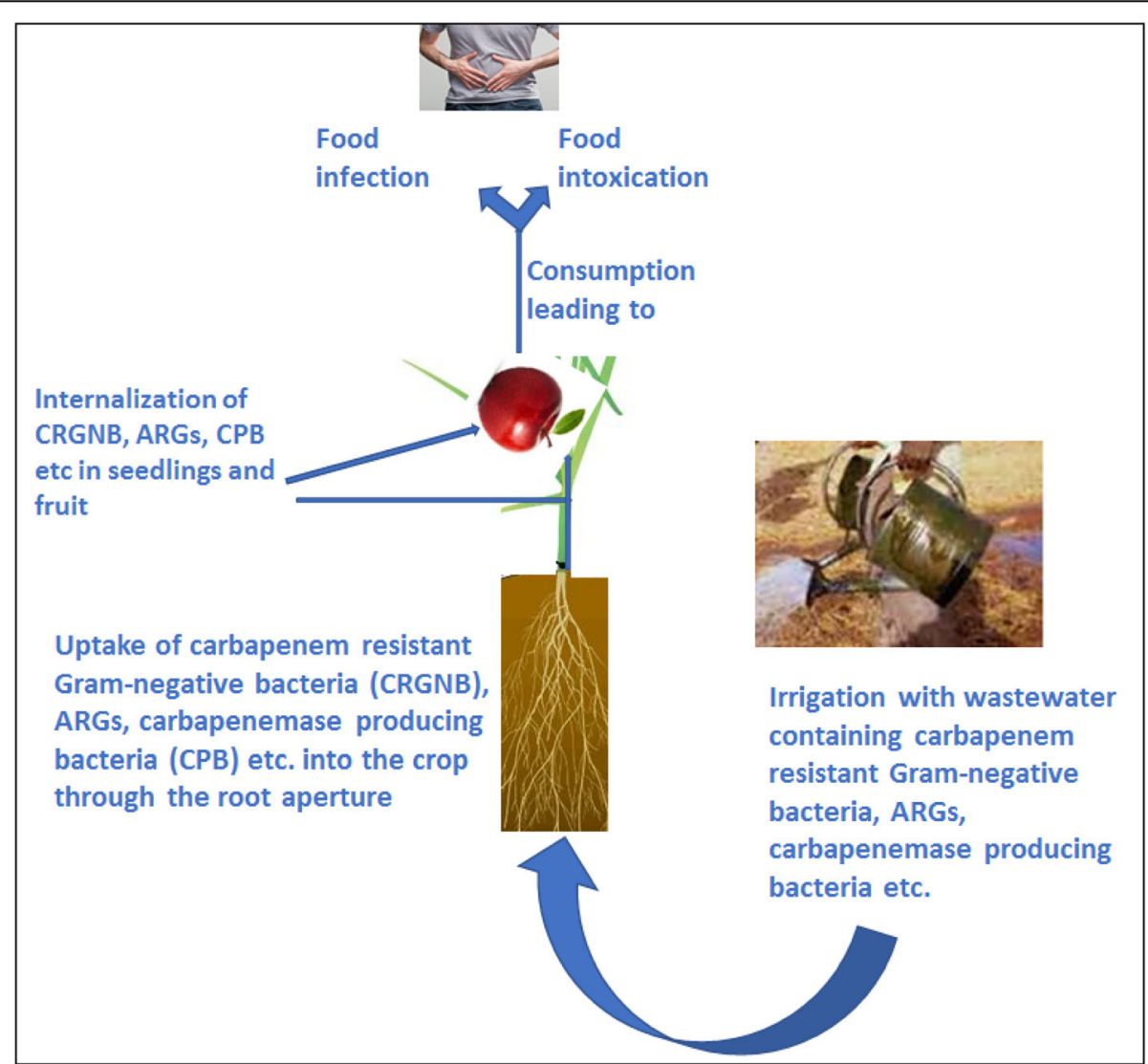

Fig. 2 Uptake and internalization of carbapenem-resistant Gram-negative bacteria (CRGNB), ARGs, carbapenemase-producing bacteria (CPB) etc. into edible fruits 
with recommendations. Hand hygiene needs to be accompanied with general hygiene as well as steps to prevent contamination of food or water source. Hands should be washed anytime one gets in contact with wastewater, treated wastewater's recipient water bodies, untreated recreation waters etc. likely contaminated with antibiotic-resistant bacteria. This will decrease the transmission of antimicrobial resistance from water matrix.

This relates with the multiple barrier approach (WHO, 2006). The multiple barrier approach prevents or reduces the contamination of drinking water by high-risk pathogens, which include CRE. Combined utilization of advanced oxidative processes coupled to UV-irradiation with chemical disinfectants possesses potentials to eliminate ARB and ARGs (Sanganyado and Gwenzi 2019), though some disinfectants may form toxic complexes with residual antibiotics in water and lyse microbial cells to release their genome enhancing gene transfer to pathogens worsening their prognosis of the infection they cause (Faleye et al. 2019).

\section{Conclusion}

In conclusion, water matrices occupy $71 \%$ of the total space in the earth and the events within these matrices affect terrestrial life. This article reviewed the antibiotic-resistant Gram-negative bacteria, especially the carbapenemresistant bacteria (classified with critical criteria for research by $\mathrm{WHO}$ ) in water. It also considered the factors predicating the reported level of resistance as well as the potentials for total antibiotic resistance due to repertoires of these factors, while not leaving behind the related human health risk. Gene transfer, mutation and genetic recombination take place more effectively in water matrices, as organisms form more protective or effective biofilms and quorum sensing. ARGs are exchanged, and the new strains return easily to human and animal lives through the food chains or contact with the environment. These scenarios have contributed to the development of multidrug resistance, pan drug resistance, extreme drug resistance and, now, total drug resistance. Water from various sources should be subjected to multibarrier screening to prevent transmission of difficult-to-treat antibiotic-resistant bacteria from water to food cycle.

\section{Acknowledgements}

We acknowledge previous colleagues whose advice and goodwill helped in developing this work. We are grateful to the South Africa Medical Research Council for financial support.

Research involving human participants and/or animals None
Authors' contributions

All authors have equal contribution. The authors read and approved the final manuscript.

\section{Funding}

The research was supported by SAMRC Microbial Water Quality Monitoring Centre, University of Fort Hare, Alice, South Africa.

Availability of data and materials

The supporting data are available with the corresponding author.

Ethics approval and consent to participate

Not applicable

\section{Consent for publication}

Not applicable

\section{Competing interests}

The authors declare no conflict of interest.

\section{Author details}

'Department of Microbiology, University of Uyo, PMB 1017, Akwa-lbom State, Uyo, Nigeria. ${ }^{2}$ Department of Biochemistry and Microbiology, University of Fort Hare, Alice 5700, South Africa. ${ }^{3}$ SAMRC Microbial Water Quality Monitoring Centre, University of Fort Hare, Alice, South Africa.

Received: 12 March 2020 Accepted: 20 May 2020

Published online: 25 June 2020

\section{References}

Adam MA, Elhag WI (2018) Prevalence of metallo- $\beta$-lactamase acquired genes among carbapenems susceptible and resistant gram-negative clinical isolates using multiplex PCR, Khartoum hospitals, Khartoum Sudan. BMC Infect Dis 18:668-687

Adefurin A, Sammons H, Jacqz-Aigrain E, Choonara I (2011) Ciprofloxacin safety in paediatrics: a systematic review. Arch Dis Child 96(9):874-880

Adegoke AA, Awolusi OO, Stenström TA (2016) Organic fertilizers: public health intricacies. In: Larramendy M (ed) Organic fertilizers-from basic concepts to applied outcomes. INTECH, Vienna, Austria

Adegoke AA, Okoh Al (2011) Prevalence, antibiotic susceptibility profile and extended spectrum $\beta$-lactamase production among Escherichia coli from high vaginal swab (HVS). Afr J Pharm Pharmacol 5(10):1287-1291

Adegoke AA, Okoh Al (2014) Species diversity and antibiotic resistance properties of staphylococcus of farm animal origin in Nkonkobe municipality. Fol Microbiol 59:133-140

Adegoke AA, Okoh Al. Antibiogram of Stenotrophomonas maltophilia isolated from Nkonkobe municipality, eastern Cape Province, South Africa. Jundishapur J Microbiol. 2015 8:e13975. doi: https://doi.org/10.5812/jjm. 13975

Adegoke AA, Stenström TA, Okoh Al (2017) Stenotrophomonas maltophilia as an emerging ubiquitous pathogen: looking beyond contemporary antibiotic therapy. Front Microbiol 8:2276

Adegoke AA, Tom M, Okoh Al, Jacob S (2010) Studies on multiple antibiotic resistant bacteria isolated from surgical site infection. Sci Res Essays 5(24): 3876-3881

Adesoji AT, Ogunjobi AA (2016) Detection of extended spectrum beta-lactamases resistance genes among bacteria isolated from selected drinking water distribution channels in southwestern Nigeria. Biomed Res Int:7149-7295

Akiba M, Sekizuka T, Yamashita A, Kuroda M, Fuji Y, Murata M et al (2016) Distribution and relationships of antimicrobial resistance determinants among extended-spectrum-cephalosporin resistant or carbapenem-resistant Escherichia coli isolates from rivers and sewage treatment plants in India. Antimicrob Agents Chemother 60:2972-2980

Al Yousef SA, Farrag ES, Ali AM, Mahmoud SY (2016) Detection of extended spectrum beta-lactamase producing Escherichia coli on water at Hafr Al Batin, Saudi Arabia. J Pollut Eff Cont 4:155

Amine AEK (2013) Extended spectrum beta-lactamase producing bacteria in waste water Alexandria, Egypt. Inter J Biosc Biochem Bioinform 6(3):605-608

An JH, Kim YH, Moon JE, Kim SH, Kang SJ, Park KH et al (2017) Active surveillance for carbapenem-resistant Acinetobacter baumannii in a medical intensive care 
unit: can it predict and reduce subsequent infections and the use of colistin? Am J Infect Control 45:667-672

Arnold RS, Thom KA, Sharma S, Phillips M, Kristie-Johnson J, Morgan DJ (2011) Emergence of Klebsiella pneumoniae carbapenemase-producing bacteria. South Med J 104(1):40-45

Asit KC (2016) Multi-drug resistant genes in bacteria and 21st century problems associated with antibiotic therapy. Biotechnol Ind J 12:114

Baker-Austin C, Wright MS, Stepanauskas R, McArthur JV (2006) Co-selection of antibiotic and metal resistance. Trends Microbiol 14(4):176-182

Ben-David D, Maor Y, Keller N, Regev-Yochay G, Tal I, Shachar D et al (2010) Potential role of active surveillance in the control of a hospital-wide outbreak of carbapenem-resistant Klebsiella pneumoniae infection. Infect Control Hosp Epidemiol 31:620-626

Bennett JW, Herrera ML, Lewis JS, Wickes BW, Jorgensen JH (2009) KPC-2producing Enterobacter cloacae and Pseudomonas putida coinfection in a liver transplant recipient. Antimicrob Agents Chemother 53:292-294

Berrazeg M, Diene SM, Medjahed L, Parola P, Drissi M, Raoult D et al (2014) New Delhi metallo-beta-lactamase around the world: an eReview using Google maps. Euro Surveill 19:20809

Bialvaei AZ, Kafil HS, Asgharzadeh M, Ebrahimzadeh LH, Aghazadeh M (2015) Dissemination of carbapenemases producing gram-negative bacteria in the Middle East. Iran J Microbiol 7:226-246

Blaak A, Lynch G, Italiaander R, Hamidjaja RA, Schets FM, de Roda Husman AM (2015) Multidrug-resistant and extended spectrum beta-lactamaseproducing Escherichia coli in Dutch surface water and wastewater. PLoS One 10:6-15

Bouakline A, Lacroix C, Roux N, Gangneux JP, Derouin F (2000) Fungal contamination of food in hematology units. J Clin Microbiol 38:4272-4273

Bradford PA (2001) Extended-spectrum beta-lactamases in the 21st century: characterization, epidemiology, and detection of this important resistance threat. Clin Microbiol Rev 14:933-951

Branswell H A. Nevada woman dies of a superbug resistant to every available antibiotic in the US. (2017) Available https://www.statnews.com/2017/01/12/ nevada-woman-superbug-resistant/

Brenier-Pinchart MP, Faure O, Garban F, Fricker-Hidalgo H, Mallaret MR, Trens A, Lebeau B, Pelloux H, Grillot R (2006) Ten-year surveillance of fungal contamination of food within a protected haematological unit. Mycoses. 49 : $421-425$

Buehrle DJ, Shields RK, Clarke LG, Potoski BA, Clancy CJ, Nguyen MH (2017) Carbapenem-resistant Pseudomonas aeruginosa bacteremia: risk factors for mortality and microbiologic treatment failure. Antimicrob Agents Chemother 61:e01243-e01216

Bush K (2008) Extended-spectrum $\beta$-lactamases in North America, 1987-2006. Clin Microbiol Infect 14:134-143

Calfee D, Jenkins SG (2008) Use of active surveillance cultures to detect asymptomatic colonization with carbapenem-resistant Klebsiella pneumoniae in intensive care unit patients. Infect Control Hosp Epidemiol 29:966-968

Campos J, Cristino L, Peixe L, Antunes P (2016) MCR-1 in multidrug-resistant and copper tolerant clinically relevant salmonella 1,4,[5],12:i:- and S. Rissen clones in Portugal, 2011 to 2015. Euro Surveill 21

Canton R, Akova M, Carmeli Y (2012) Rapid evolution and spread of carbapenemases among Enterobacteriaceae in Europe. Clin Microbiol Infect 18:413-431

Canton R, Oliver A, Coque TM, Varela-Mdel C, Perez-Diaz JC, Baquero F (2002) Epidemiology of extended-spectrum beta-lactamase-producing Enterobacter isolates in a Spanish hospital during a 12-year period. J Clin Microbiol 40: 1237-1243

Castilho SRA, Godoy CSM, Guilarde AO, Cardoso JL, André MCP, Junqueira-Kipnis AP et al (2017) Acinetobacter baumannii strains isolated from patients in intensive care units in Goiania, Brazil: molecular and drug susceptibility profiles. PLoS One 12(5):e0176790

Centers for Disease Control and Prevention. CRE toolkit-guidance for control of carbapenem-resistant Enterobacteriaceae (CRE) 2012. Available at: http:// www.cdc.gov/hai/organisms/cre/cre-toolkit/index.html. Accessed 24 May 2017.

Cheon S, Kim MJ, Yun SJ, Moon JY, Kim YS (2016) Controlling endemic multidrug resistant Acinetobacter baumannii in intensive care units using antimicrobial stewardship and infection control. Korean J Intern Med 31:367-374

Cho SY, Huh HJ, Baek JY, Chung NY, Ryu JG, Ki CS et al (2015) Klebsiella pneumoniae co-producing NDM-5 and OXA-181 carbapenemases, South Korea. Emerg Infect Dis 21:1088-1089
Choi SH, Kim EY, Kim YJ (2013) Systemic use of fluoroquinolone in children. Korean J Pediatr 56:196-201

CLSI, Clinical and Laboratory Standards Institute (2017) Performance standards for antimicrobial susceptibility testing; 27th edition. M100-S27. Wayne, PA, CLSI

Davies J, Davies D (2010) Origins and evolution of antibiotic resistance. Microbiol Mol Biol Rev 74:417-433

D'Costa VM, McGrann KM, Hughes DW, Wright GD (2006) Sampling the antibiotic resistome. Science 311:374-377

Delgado DYC, Barrigas ZPT, Astutillo SGO, Jaramillo APA, Ausili A (2016) Detection and molecular characterization of $\beta$-lactamase genes in clinical isolates of gram-negative bacteria in southern Ecuador. Braz J Infect Dis 20:627-630

Deng X, Ran L, Wu S, Ke B, He D, Yang X, Zhang Y, Ke C, Klena JD, Yan M, Feng Z, Kan B, Liu X, Mikoleit M, Varma JK (2012) Laboratory-based surveillance of non-typhoidal salmonella infections in Guangdong Province, China. Foodborne Pathog Dis 9(4):305-312

Diancourt L, Passet V, Verhoef J, Grimont PAD, Brisse S (2005) Multilocus sequence typing of Klebsiella pneumoniae nosocomial isolates. J Clin Microbiol 43:4178-4182

Economou V, Gousia P (2015) Agriculture and food animals as a source of antimicrobial-resistant bacteria. Infect Drug Resist 8:49-61

Endimiani A, Hujer AM, Perez F (2009) Characterization of blaKPC-containing Klebsiella pneumoniae isolates detected in different institutions in the eastern USA. J Antimicrob Chemother 63:427-437

Faleye AC, Adegoke AA, Ramluckan K, Fick J, Bux F, Stenström TA (2019) Concentration and reduction of antibiotic residues in selected wastewater treatment plants and receiving waterbodies in Durban, South Africa. Sci Total Environ 678:10-20

Fang L, Li X, Li L, Li S, Liao X, Sun J et al (2016) Co-spread of metal and antibiotic resistance within $\mathrm{ST} 3-\mathrm{InCH} 12$ plasmids from $\mathrm{E}$. coli isolates of food-producing animals. Sci Rep 6:25312

Figueira V, Vaz-Moreira I, Silva M, Manaia CM (2011) Diversity and antibiotic resistance of Aeromonas spp. in drinking and waste water treatment plants. Water Res 45:5599-5611

Founou LL, Founou RC, Essack SY (2016) Antibiotic resistance in the food chain: a developing country-perspective. Front Microbiol 7:1881

Freitas DY, Araújo S, Folador ARC, Ramos RTJ, Azevedo JSN, Tacão M et al (2019) Extended spectrum beta-lactamase-producing gram-negative bacteria recovered from an Amazonian lake near the city of Belém, Brazil. Front Microbiol 10:364

Galler H, Feierl G, Petternel C, Peinthaler FF, Haas D, Grisold AJ et al (2014) KPC-2 and OXA-48 carbapenemase harbouring Enterobacteriaceae detected in an Austrian wastewater treatment plant. Clin Microbiol Infect 20:132-134

Ghafourian S, Sadeghifard N, Soheili S, Sekawi Z (2015) Extended spectrum betalactamases: definition, classification and epidemiology. Curr Issues Mol Biol 17:11-22

Golberg D, Kroupitski Y, Belausov E, Pinto R, Sela S (2011) Salmonella Typhimurium internalization is variable in leafy vegetables and fresh herbs. Int J Food Microbiol 145(1):250-257

Goldman JA, Kearns GL (2010) Fluoroquinolone use in paediatrics: focus on safety and place in therapy. 18th expert committee on the selection and use of essential medicines. downloaded from http://www.who.int/selectionmedicines/ committees/expert/18/applications/fluoroquinolone_review.pdf

Gordon AEK, Mathers AJ, Cheong EYL, Gottlieb T, Kotay S, Walker AS et al (2017) The hospital water environment as a reservoir for carbapenem-resistant organisms causing hospital-acquired infections-a systematic review of the literature. Clin Infect Dis 64:1435-1444

Goroncy-Bermes P, Koburger T, Meyer B (2010) Impact of the amount of hand rub applied in hygienic hand disinfection on the reduction of microbial counts on hands. J Hosp Infect. 74:212-218

Guyomard-Rabenirina S, Dartron C, Falord M, Sadikalay S, Ducat C, Richard V (2017) Resistance to antimicrobial drugs in different surface waters and wastewaters of Guadeloupe. PLoS One 12:e0173155

Heller I, Grif K, Orth D (2012) Emergence of VIM-1-carbapenemase-producing Enterobacter cloacae in Tyrol, Austria. J Med Microbiol 61:567-571

Hellmér M, Paxéus N, Magnius L, Enache L, Arnholm B, Johansson A et al (2014) Detection of pathogenic viruses in sewage provided early warnings of hepatitis a virus and norovirus outbreaks. Appl Environ Microbiol 80(21):6771-6781

Hoenigl M, Valentin T, Zarfel G (2012) Nosocomial outbreak of Klebsiella pneumoniae carbapenemase-producing Klebsiella oxytoca in Austria. Antimicrob Agents Chemother 56:2158-2161

Hrenovic J, Ganjto M, Goic-Barisic I (2017) Carbapenem-resistant bacteria in a secondary wastewater treatment plant. Water SA 43:186-191 
Isozumi R, Yoshimatsu K, Yamashiro T, Hasebe F, Nguyen BM, Ngo TC et al (2012) BlaNDM-1-positive Klebsiella pneumoniae from environment, Vietnam. Emerg Infect Dis 18(8):1383-1385

Iwu CD, Okoh Al (2019) Preharvest transmission routes of fresh produce associated bacterial pathogens with outbreak potentials: a review. Int J Environ Res Public Health 16:4407

Khan GA, Berglund B, Khan MK, Lindgren PE, Fick J (2013) Occurrence and abundance of antibiotics and resistance genes in rivers, canal and near drug formulation facilities-a study in Pakistan. PLoS One 8:e62712

Kittinger C, Lipp M, Folli B, Kirschner A, Baumert R, Galler H et al (2016) Enterobacteriaceae isolated from the river Danube: antibiotic resistances, with a focus on the presence of ESBL and carbapenemases. PLoS One 11(11): e0165820

Kochar S, Sheard T, Sharma R, Hui A, Tolentino E, Allen G et al (2009) Success of an infection control program to reduce the spread of carbapenem-resistant Klebsiella pneumoniae. Infect Control Hosp Epidemiol 30:447-452

Kontopoulou K, Protonotariou E, Vasilakos K (2010) Hospital outbreak caused by Klebsiella pneumoniae producing KPC-2 $\beta$-lactamase resistant to colistin. J Hosp Infect 76:70-73

Kotsana D, Wijesooriya WR, Korman TM, Gillespie EE, Wright L, Snook K et al (2014) "Down the drain": carbapenem-resistant bacteria in intensive care unit patients and handwashing sinks. Med J Aust 198:267-269

Li D, Yang M, Hu J, Zhang J, Liu R, Gu X et al (2009) Antibiotic-resistance profile in environmental bacteria isolated from penicillin production wastewater treatment plant and the receiving river. Environ Microbiol 11:1506-1517

Li LG, Xia Y, Zhang T (2016) Co-occurrence of antibiotic and metal resistance genes revealed in complete genome collection. ISME J 11:651-662

Liakopoulos A, Mevius D, Ceccarelli D (2016) A review of SHV extended-spectrum beta-lactamases: neglected yet ubiquitous. Front Microbiol 7:1374

Liu A, Tran L, Becket E, Lee K, Chinn L, Park E et al (2010) Antibiotic sensitivity profiles determined with an Escherichia coli gene knockout collection: generating an antibiotic bar code. Antimicrob Agents Chemother 54:1393-1403

Liu J, Li G, Lin L, Wu X, Huang S, Zhou Y, Zhao Z (2016) Association of antibiotic resistance with SHV-12 extended-spectrum $\beta$-lactamase in Enterobacter cloacae. Exp Ther Med 11:269-276

Liu Q, Li X, Li W, Du X, He JQ, Tao C, Feng Y (2015) Influence of carbapenem resistance on mortality of patients with Pseudomonas aeruginosa infection: a meta-analysis. Sci Rep 5:11715

Lutgring JD, Limbago BM (2016) The problem of carbapenemase producingcarbapenem- resistant-Enterobacteriaceae detection. J Clin Microbiol 54:529-534

Lv L, Jiang T, Zhang S, Yu X (2014) Exposure to mutagenic disinfection byproducts leads to increase of antibiotic resistance in Pseudomonas aeruginosa. Environ Sci Technol:8188-8195

Lv L, Yu X, Xu Q, Ye C (2015) Induction of bacterial antibiotic resistance by mutagenic halogenated nitrogenous disinfection byproducts. Environ Pollut 205:291-298

Macinga DR, Beausoleil CM, Campbell E, Mulberry G, Brady A, Edmonds SL et al (2011) Quest for a realistic in vivo test method for antimicrobial hand-rub agents: introduction of a low-volume hand contamination procedure. Appl Environ Microbiol 77:8588-8594

Magalhães MJ, Pontes G, Serra PT, Balieiro A, Castro D, Pieri FA (2016) Multidrug resistant Pseudomonas aeruginosa survey in a stream receiving effluents from ineffective wastewater hospital plants. BMC Microbiol 16:193

Majowicz SE, Musto J, Scallan E, Angulo FJ, Kirk M, O'Brien SJ, Jones TF, Fazil A, Hoekstra RM (2010) The global burden of nontyphoidal salmonella gastroenteritis. Clin Infect Dis 50(6):882-889

Manhal FS, Hashim JQ (2016) Evaluation of extended-spectrum beta-lactamases in gram negative rods isolated from Tigris River in Baghdad City. Inter J Adv Res 4:1144-1150

Marti R, Scott A, Tien Y, Murray R, Sabourin L, Zhang Y et al (2013) Impact of manure fertilization on the abundance of antibiotic-resistant bacteria and frequency of detection of antibiotic resistance genes in soil and on vegetables at harvest. Appl Environ Microbiol 79:5701-5709

McGowan JE (2006) Resistance in non-fermenting gram-negative bacteria: multidrug resistance to the maximum. Am J Med 119:S29-S36

Munoz-Price LS, De La Cuesta C, Adams S, Wyckoff M, Cleary T, McCurdy SP et al (2010a) Successful eradication of a monoclonal strain of Klebsiella pneumoniae during a K. pneumoniae carbapenemase-producing $K$. pneumoniae outbreak in a surgical intensive care unit in Miami, Florida. Infect Control Hosp Epidemiol 31:1074-1077

Munoz-Price LS, Hayden MK, Lolans K, Won S, Calvert K, Lin M et al (2010b) Successful control of an outbreak of Klebsiella pneumoniae carbapenemase- producing K. pneumoniae at a long-term acute care hospital. Infect Control Hosp Epidemiol 31:341-347

Nordmann P, Dortet L, Poirel L (2012) Carbapenem resistance in Enterobacteriaceae: here is the storm. Trends Mol Med 18:263-272

Nordmann P, Naas T, Poirel L (2011) Global spread of carbapenemase-producing Enterobacteriaceae. Emerg Infect Dis 17:1791-1798

Nordmann P, Poirel L (2002) Emerging carbapenemases in gram-negative aerobes. Clin Microbiol Infect 8:321-331

Pal C, Bengtsson-Palme J, Kristiansson E, Larsson DG (2015) Co-occurrence of resistance genes to antibiotics, biocides and metals reveals novel insights into their co-selection potential. BMC Genomics 16:964

Palmore TN, Henderson DK (2013) Managing transmission of carbapenemresistant Enterobacteriaceae in healthcare settings: a view from the trenches. Clin Infect Dis 57:1593-1599

Paterson DL, Hujer KM, Hujer AM, Yeiser B, Bonomo MD, Rice LB et al (2003) Extended-spectrum beta-lactamases in Klebsiella pneumoniae bloodstream isolates from seven countries: dominance and widespread prevalence of SHV- and CTX-M-type beta-lactamases. Antimicrob Agents Chemother 47: 3554-3560

Peleg AY, Seifert H, Paterson DL (2008) Acinetobacter baumannii: emergence of a successful pathogen. Clin Microbiol Rev 21:538-582

Picao RC, Cardoso JP, Campana EH, Nicoletti AG, FVB P, Assis DM et al (2013) The route of antimicrobial resistance from the hospital effluent to the environment: focus on the occurrence of KPC-producing Aeromonas spp. and Enterobacteriaceae in sewage. Diagn Microbiol Infect Dis 76(1):80e85

Picão RC, Cardoso JP, Campana EH, Nicoletti AG, Petrolini FVB, Assis DM et al (2013) The route of antimicrobial resistance from the hospital effluent to the environment: focus on the occurrence of KPC-producing Aeromonas spp. and Enterobacteriaceae in sewage. Diag Microbiol Infect Dis, Dis. 76:80-85

Poirel L, Barbosa-Vasconcelos A, Simoes RR, Da Costa PM, Liu W, Nordmann P (2012) Environmental KPC-producing Escherichia coli isolates in Portugal. Antimicrob Agents Chemother 56:1662-1663

Potron A, Nordmann P, Lafeuille E, Al Maskari Z, Al Rashdi F, Poirel L (2011) Characterization of OXA-181, a carbapenem- hydrolyzing class D $\beta$-lactamase from Klebsiella pneumoniae. Antimicrob Agents Chemother 55:4896-4899

Ramirez-Castillo FY, Loera-Muro A, Jacques M, Garneau P, Avelar-Gonzalez FJ, Harel J, Guerrero-Barrera AL (2015) Waterborne pathogens: detection methods and challenges. Pathogens. 4:307-334. https://doi.org/10.3390/ pathogens4020307

Reinthaler FF, Galler H, Feierl G, Haas D, Leitner E, Mascher F et al (2013) Resistance patterns of Escherichia coli isolated from sewage sludge in comparison with those isolated from human patients in 2000 and 2009. J Water Health 11:13-20

Rodríguez-Baño J, Pascual A (2008) Clinical significance of extended-spectrum beta-lactamases. Expert Rev Anti-Infect Ther 6:671-683

Romero JL, Grande-Burgos MJ, Pérez-Pulido R, Gálvez A, Lucas R (2017) Resistance to antibiotics, biocides, preservatives and metals in bacteria isolated from seafoods: co-selection of strains resistant or tolerant to different classes of compounds. Front Microbiol 8:1650

Sanganyado E, Gwenzi W (2019) Antibiotic resistance in drinking water systems: occurrence, removal, and human health risks. Sci Total Environ 669:785-797

Sickbert-Bennett EE, Weber DJ, Gergen-Teague MF, Rutala WA (2004) The effects of test variables on the efficacy of hand hygiene agents. Am J Infect Control 32:69-83

Skariyachan S, Mahajanakatti AB, Grandhi NJ, Prasanna A, Sen B, Sharma N et al (2015) Environmental monitoring of bacterial contamination and antibiotic resistance patterns of the fecal coliforms isolated from Cauvery River, a major drinking water source in Karnataka, India. Environ Monit Assess 87:279-291

Sosa V, Schlapp G, Zunino P (2006) Proteus mirabilis isolates of different origins do not show correlation with virulence attributes and can colonize the urinary tract of mice. Microbiol. 152:2149-2157

Stenström TA, Okoh Al, Adegoke AA (2016) Antibiogram of environmental isolates of Acinetobacter calcoaceticus from Nkonkobe municipality, South Africa. Fresenius Environ Bull 25:3059-3065

Tacao M, Correia A, Henriques IS (2015) Low prevalence of carbapenem-resistant bacteria in river water: resistance is mostly related to intrinsic mechanisms. Microb Drug Resist 21:497-506

Thanner S, Drissner D, Walsh F (2016) Antimicrobial resistance in agriculture. MBio. 7:e2227-e2215 
Wales AD, Davies RH (2015) Co-selection of resistance to antibiotics, biocides and heavy metals, and its relevance to foodborne pathogens. Antibiotics. 4:567-604

Watanabe T, Ohba H, Asanoma M, Hasei T, Takamura T, Terao Y et al (2006) Isolation and identification of non-chlorinated phenylbenzotriazole (non(IPBTA)-type mutagens in the Ho River in Shizuoka prefecture, Japan. Mutation Res 609:13-145

WHO. World Health Organization priority pathogens list for R\&D of new antibiotics. 5, (2017), http://www.who.int/medicines/publications/WHO-PPLShort_Summary_25Feb-ET_NM_WHO.pdf. Accessed 15 Jan 2018

World Health Organization (WHO) (2006) Guidelines for the safe use of wastewater, excreta and greywater: wastewater use in agriculture - volume 2. World Health Organization, Geneva

Xu H, Broersma K, Miao V, Davies J (2011) Class 1 and class 2 integrons in multidrug-resistant gram-negative bacteria isolated from the Salmon River, British Columbia. Can J Microbiol 57:460-467

Yigit H, Queenan AM, Anderson GJ, Domenech-Sanchez A, Biddle JW, Steward CD et al (2001) Novel carbapenem-hydrolyzing beta-lactamase, KPC-1, from a carbapenem-resistant strain of Klebsiella pneumoniae. Antimicrob Agents Chemother 45:1151-1161

Zarfel G, Hoenigl M, Wurstl BG, Leitner E, Salzer HJF, Valentin T et al (2011) Emergence of carbapenem-resistant Enterobacteriaceae in Austria, 20012010. Clin Microbiol Infect 17:E5-E8

Zarkotou O, Pournaras S, Voulgari E (2010) Risk factors and outcomes associated with acquisition of colistin-resistant KPC-producing Klebsiella pneumoniae: a matched case-control study. J Clin Microbiol 48:2271-2274

Zavascki AP, Goldani LZ, Li J, Nation RL (2007) Polymyxin B for the treatment of multidrug-resistant pathogens: a critical review. J Antimicrob Chemother 60: 1206-1215

Zhang T, Zhang XX, Ye L (2011) Plasmid metagenome reveals high levels of antibiotic resistance genes and mobile genetic elements inactivated sludge. PLoS One 6:e26041

Zhang Y, Chen XL, Huang AW, Liu SL, Liu WJ, Zhang N et al (2016) Mortality attributable to carbapenem-resistant Pseudomonas aeruginosa bacteremia: a meta-analysis of cohort studies. Emerg Microbes Infect 5:e27. https://doi.org/ 10.1038/emi.2016.22

Zuccato E, Castiglioni S, Fanelli R (2005) Identification of the pharmaceuticals for human use contaminating the Italian aquatic environment. J Hazard Mater 122:205-209

Zurfluh K, Hachler H, Nuesch-Inderbinen M, Stephan R (2013) Characteristics of extended-spectrum $\beta$-lactamase- and carbapenemase-producing Enterobacteriaceae isolates from rivers and lakes in Switzerland. Appl Environ Microbiol 79:3021-3026

\section{Publisher's Note}

Springer Nature remains neutral with regard to jurisdictional claims in published maps and institutional affiliations.

Ready to submit your research? Choose BMC and benefit from:

- fast, convenient online submission

- thorough peer review by experienced researchers in your field

- rapid publication on acceptance

- support for research data, including large and complex data types

- gold Open Access which fosters wider collaboration and increased citations

- maximum visibility for your research: over $100 \mathrm{M}$ website views per year

At $\mathrm{BMC}$, research is always in progress.

Learn more biomedcentral.com/submissions 